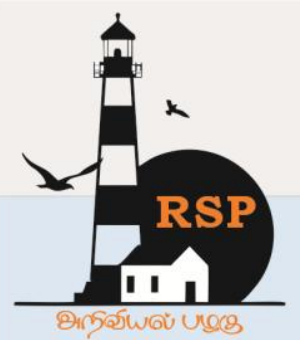

INTERNATIONAL RESEARCH JOURNAL ON ADVANCED SCIENCE HUB

Special Issue of First International Conference on Engineering, Science, and Technology (ICEST 2021)

\title{
Performance enhancement of Waffles (Appalam) drying using mixed mode
}

\section{solar dryer}

Dr. C. Subramanian ${ }^{1}$, Dr. P. Chandru Deva Kannan ${ }^{2}$, L. Karthikeyan ${ }^{3}$, G. Prakashraj ${ }^{4}$, P. Nadaraj ${ }^{5}$

${ }^{1,2}$ Professor, Dept of Mechanical Engineering, Christ College of engineering and Technology, Pondicherry, India

${ }^{3,4,5}$ Student, Dept of Mechanical Engineering, Christ College of engineering and Technology, Pondicherry, India

csmanianmec@gmail.com ${ }^{1}$, chandru4u1983@gmail.com ${ }^{2}$

\begin{abstract}
In this present work, investigations are made to study the performance of mixed mode solar dryer for waffles drying. The design, development and performance analysis of mixed mode solar dryer for drying of waffles (appalam) is reported. The design was developed under metrological conditions at Puducherry. A novel numerical model was developed to enhance the productivity rate by reducing the drying time of the waffles (appalam).
\end{abstract}

Keywords: Mixed mode solar dryer, Productivity Rate, Waffles, Analysis

\section{Introduction}

The main source of all capital for renewable energy is solar energy. To solve current energy crises, improvement in sustainable solar energy technologies to harness the tremendous power of the sun is required. Solar power has tremendous potential to meet the rising energy needs of the growing population. Among the rural farmers of developing countries, solar drying technology can be easily adopted. In the case of waffles (appalam) drying, the drying process is of particular importance, since they are especially susceptible to insects.

\subsection{Solar energy}

The earth's surface has received approximately $1014 \mathrm{KW}$ of solar energy from the sun. The energy equivalent of around $1 \mathrm{HP}$ or $1 \mathrm{KW}$ is supplied by one square metre of land exposed to direct sunlight. Large-scale conversion of solar energy involves a large investment of resources. In contrast to other sources of electricity, solar energy has some strong advantages. Planet has obtained from the sun approximately $1014 \mathrm{KW}$ of solar energy. Approximately $1 \mathrm{HP}$ or $1 \mathrm{KW}$ of energy equivalent is given. In contrast to other sources of electricity, solar energy has some strong advantages. Solar radiation does not contaminate the atmosphere or geoparadise environmental equilibrium. It prevents serious problems such as mining, extraction and transportation.[1-5]

\subsection{Solar drying}

Sample Drying, long before frying, was probably the first food preservation tool ever used by man. The appropriate food preservation technology for solar dryers. The earliest method of drying farm produce ever known to man is "Sun drying". It includes simply laying the farm products on mats, roofs or drying floors in the sun. The approach often involves vast areas of land that take time and are highly labour intensive. Solar dryers are specialized instruments in the solar drying process that control the drying process. They protect agricultural produce from insect pests, dust and 
www.rspsciencehub.com

rain damage. Higher temperatures, lower relative humidity and lower product moisture content are produced by solar dryers. Solar dryers can be considered one of the solutions to the food and energy shortages of the planet. Solar dryers are mainly divided into three groups, which are
$\checkmark$ Direct solar drying
$\checkmark$ Indirect solar drying
$\checkmark \quad$ Mixed mode solar drying

\subsection{Direct solar drying}

A solar cabinet dryer is also regarded as the working theory of direct solar crop drying. The air entering the cabinet from below and exiting through the top exit takes away the moisture here. A percentage of the overall solar radiation that affects the glass cover is reflected back into the atmosphere and the remainder is transmitted within the cabinet.

\subsection{Indirect solar dryer}

Inside an opaque drying cabinet, the crops in these indirect solar dryers are located in trays or shelves. The warm air is allowed to flow through the wet crop and over it. Owing to the distinction of moisture concentration, drying takes place.

\subsection{Mixed mode solar dryer}

The solar dryers combine the characteristics of direct and indirect solar energy dryers of the mixed-mode kind. In both the flat plate air heater and the drying chamber, the storage of solar energy takes place. Solar energy will also be obtained by the outer portion of the dryer .

For domestic purposes, step-type solar dryers are widely used. Solar tunnel dryers are typically used in manufacturing industries.

\section{Experimental arrangements}

The mixed-mode has a pre-heating mechanism for the air via a solar air heater. Food items are respectively heated by hot air and direct exposure to solar radiation from the air heater. The mixed solar dryer mode consists primarily of four components they are,
$\checkmark$ Flat plate collector
$\checkmark$ Blower
$\checkmark$ Drying chamber
$\checkmark$ Thermocouple

A flat-plate solar air heater and a drying chamber were part of the laboratory model. The collector dryer assembly consists of a $1 \mathrm{~mm}$ aluminium sheet
Volume 03 Issue 01S January 2021

of smoke black coating used as a solar radiation absorber board.[6-10]

\subsection{Flat plate collector}

A flat-plate collector (FPC) is a device for collecting and converting solar energy into thermal energy. It is the basis of solar thermal systems in a medium temperature range for many applications. A traditional solar air heater typically consist of an absorber plate with a parallel plate below providing a narrow passage into which the air to be heated flows.

\subsection{Blower}

It is a device that is used and sent through the ambient air to suck the air from the surrounding.

\subsection{Drying chamber}

The gross solar dryer scale is $400 \times 330 \times 330 \mathrm{~mm}$. With the assistance of sheet metal, the blower is paired with the solar air heater. For a certain thickness and glass cover, the dryer is covered with wood.

\subsection{Thermocouple}

A thermocouple is a device used to measure temperature accurately. It is often made of two dissimilar metals. A device in which a temperature difference is deduced from a thermoelectric potential calculation at the ends of a pair of separate metal wires. The presence of a temperature gradient in a metal or alloy results in the setting up of an electrical potential gradient along the temperature gradient.

\subsection{Working fluid}

Air is used as working fluid. The properties of air at $30^{\circ} \mathrm{C}$

Density $=1.165 \mathrm{Kg} / \mathrm{m} 3$

Specific heat capacity $=1005 \mathrm{~J} / \mathrm{Kg}-\mathrm{K}$

Thermal conductivity $=0.02675 \mathrm{~W} / \mathrm{m}-\mathrm{k}$

Kinematic viscosity $=15.06 \times 10-6 \mathrm{~m} 2 / \mathrm{s}$

Absolute viscosity $=18.63 \times 10-6 \mathrm{~N}-\mathrm{s} / \mathrm{m} 2$

Prandtl number $=0.701$

\section{Design calculation}

Determination of Flux Absorbed by Absorber Plate:

For March 21 - at 12:00Pm

$\mathrm{Ig}=950 \mathrm{~W} / \mathrm{m}^{2}$

Latitude of puducherry $(\phi)=11^{\circ} 55^{\prime}$

Angle of tilt $(\beta)$ of solar air heater $=10^{\circ}+$ lat $(\phi)$

$\beta=21^{\circ} 55^{\text {, }}$

Declination angle:

$\delta=23.45 \sin [(360 / 365) \times(284+n)]$ 
$\mathrm{n}$ - Number of days

$\mathrm{n}=80$

$\delta=-0^{\circ} 24$

$\omega=15[12-\mathrm{LST}]$

$\omega=0^{\circ}$

$\operatorname{Cos} \theta=(\sin \delta \times \sin (\phi-\beta))+(\cos \omega \times \cos \delta \times \cos (\phi-$ $\beta))=0.986$

$\operatorname{Cos} \theta \mathrm{z}=(\sin \delta \times \sin \phi)+(\cos \omega \times \cos \delta \times \cos (\phi))=$ 0.977

$\omega \mathrm{s}=\cos -1(-\tan \emptyset \times \tan \delta)=89^{\circ} 54^{\prime}(1.569 \mathrm{rad})$

$\omega \mathrm{st}=\cos ^{-1}(-\tan (\varnothing-\beta) \times \tan \delta)=90^{\circ} 4^{\prime}(1.572 \mathrm{rad})$

$\mathrm{Rb}=\omega \operatorname{stsin} \delta \sin (\varnothing-\beta)+\cos \delta \sin \omega \operatorname{stc} \cos (\varnothing-\beta) \omega \operatorname{ssin} \delta$

$\sin \emptyset+\cos \delta \sin \omega \operatorname{sen} \varnothing=1.01$

$\mathrm{Rd}=(1+\cos \beta) / 2=0.964$

$\operatorname{Rr}=\rho(1-\cos \beta) / 2$

Assume $\rho=0.2$

$\mathrm{Rr}=0.0072$

Io $=1.367 \times\{1+0.033 \cos (360 / 365) \times(n)\} \times(\sin$

$\delta \times \sin \phi)+(\cos \omega \times \cos \delta \times \cos (\phi)) 15$

$\mathrm{Io}=1.344 \mathrm{KW} / \mathrm{m} 2 \mathrm{IgHg}=\mathrm{IoHo}(\mathrm{a}+\mathrm{b} \cos \omega)$

$\mathrm{a}=0.409+0.5016 \sin \left(\omega \mathrm{s}-60^{\circ}\right)=0.659$

$\mathrm{b}=0.6609-0.4767 \sin \left(\omega \mathrm{s}-60^{\circ}=0.423 \mathrm{HoHg}=1.531\right.$

$\mathrm{Ho}=1 \pi \times 1.367 \times 3600 \times(1+0.033 \cos 360365 \times \mathrm{n}) \times(\omega \mathrm{ss}$

in $\delta \sin \emptyset+\cos \emptyset \cos \delta \sin \omega \mathrm{s})$

$\mathrm{Ho}=0.428 \mathrm{KW} / \mathrm{m}^{2}$

$\mathrm{Hg}=0.280 \mathrm{KW} / \mathrm{m}^{2}$

$\mathrm{Hd}=\mathrm{Hg}[1.411-1.696 \mathrm{HgHo}]=0.0844 \mathrm{KW} / \mathrm{m}^{2}$

$\mathrm{Id}=\mathrm{Hd} \times(\mathrm{IoHo})=0.265 \mathrm{KW} / \mathrm{m}^{2}$

$\mathrm{Ib}=\mathrm{Ig}-\mathrm{Id}=0.685 \mathrm{KW} / \mathrm{m}^{2}$

$\mathrm{IT}=\mathrm{Ibrb}+\mathrm{Idrd}+\mathrm{Igrr}=954 \mathrm{~W} / \mathrm{m}^{2}$

Beam radiation: $\cos \theta=0.968$

$\theta 1=9^{\circ} 35^{\prime}$

Reflective index $=1.52$

Angle of refraction $\theta 2=\sin -1(\sin \theta 1 / 1.52)$

$\theta 2=6^{\circ} 17^{\prime}$

$\rho 1=(\sin (\theta 2-\theta 1)) 2(\sin (\theta 1+\theta 2)) 2=0.044$

$\rho 2=(\tan (\theta 2-\theta 1)) 2(\tan (\theta 1+\theta 2)) 2=0.041$

$\tau \mathrm{r} 1=1-\rho 11+\rho 1=0.916$

$\tau \mathrm{r} 2=1-\rho 21+\rho 2=0.921$

$\tau \mathrm{r}=\tau \mathrm{r} 1+\tau \mathrm{r} 22=0.91916$

$\tau \mathrm{a}=0.953$

$\tau=\tau \mathrm{a} \times \tau \mathrm{r}=0.876$

$(\tau \alpha) b=\tau \times 0.99771-(1-0.9977) \times 0.11=0.875$

Diffuse radiation:

Assume angle of incident $=60^{\circ}$

$\theta 2=35^{\circ} 15^{\prime}$

Following same procedure as for beam radiation, $(\tau \alpha) \mathrm{d}=0.728$

Incident flux absorbed by absorber plate:

$\mathrm{S}=\operatorname{Ibrb}(\tau \alpha) b+\{\operatorname{Idrd}+\operatorname{Igrr}\} \times(\tau \alpha) \mathrm{d}$
$\mathrm{S}=796 \mathrm{~W} / \mathrm{m}^{2}$

Table.1. Value of Predicting Solar Radiation

\begin{tabular}{|l|l|l|l|l|l|l|l|l|}
\hline $\begin{array}{l}\text { Ime } \\
(\mathrm{h})\end{array}$ & $\begin{array}{l}\text { Hg } \\
(\mathrm{W} / \mathrm{m} 2)\end{array}$ & $\begin{array}{l}\text { Hd } \\
(\mathrm{W} / \mathrm{m} 2)\end{array}$ & $\begin{array}{l}\mathrm{b} \\
(\mathrm{W} / \mathrm{m} 2)\end{array}$ & $\begin{array}{l}\text { ld } \\
(\mathrm{W} / \mathrm{m} 2)\end{array}$ & $\begin{array}{l}\lg \\
(\mathrm{W} / \mathrm{m} 2)\end{array}$ & $\begin{array}{l}\mathrm{l} \\
(\mathrm{W} / \mathrm{m} 2)\end{array}$ & $\begin{array}{l}(\tau \alpha) \\
\text { g b }\end{array}$ & $\begin{array}{l}\mathrm{S} \\
(\mathrm{W} / \mathrm{m} 2)\end{array}$ \\
\hline $9: 00$ & 249 & 106 & 296 & 234 & 530 & 528 & 0.853 & 422 \\
$10: 00$ & 258 & 100 & 447 & 273 & 720 & 720 & 0.868 & 587 \\
$11: 00$ & 275 & 88.35 & 621 & 269 & 890 & 893 & 0.874 & 742 \\
$12: 00$ & 280 & 84.4 & 685 & 265 & 950 & 954 & 0.875 & 796 \\
$1: 00$ & 286 & 67.7 & 747 & 213 & 960 & 967 & 0.874 & 814 \\
$2: 00$ & 326 & 38.85 & 805 & 105 & 910 & 784 & 0.868 & 784 \\
$3: 00$ & 362 & 103 & 541 & 229 & 770 & 773 & 0.853 & 631 \\
$4: 00$ & 408 & 116 & 368 & 182 & 550 & 551 & 0.792 & 474 \\
$5: 00$ & 506 & 144 & 193 & 117 & 310 & 310 & 0.573 & 195 \\
\hline
\end{tabular}

\section{Determination of Area of Collector:}

Assumes,

1. Outlet temperature of collector $=60^{\circ} \mathrm{C}$

2. Width of collector $=600 \mathrm{~mm}$

3. Mass flow rate $=0.024 \mathrm{Kg} / \mathrm{s}$

4. Ambient temperature $=30^{\circ} \mathrm{C}$

$\mathrm{Qu}=\mathrm{S} \times \mathrm{Ap}$

$\mathrm{Qu}=\mathrm{m} \times \mathrm{Cp} \times \Delta \mathrm{T}$

$\mathrm{Ap}=\mathrm{m} \times \mathrm{Cp} \times \Delta \mathrm{T} S$

$\mathrm{Ap}=0.024 \times 1005 \times 30796=0.90 \mathrm{~m} 2$

Length $=$ Area $/$ width

$\mathrm{L}=0.90 / 0.6$

$\mathrm{L}=1.5 \mathrm{~m}$

\section{Experimental procedure}

$>$ Initially the solar radiations are strikes the absorber plate through the glass cover.

$>$ There are two types of radiations comes from sun. They are shorter wavelength and another one is longer wavelength radiations.

$>$ The longer wavelength radiations are reflected back and shorter wavelength radiations are arrested in the collector, because shorter wavelengths have lower intensity. So the absorber plate get heated.

$>$ The working fluid is used in this system is air in forced convection using blower.

$>$ Placing baffles on the absorber plate, it can enhances the heat transfer between absorber plate and working fluid.

$>$ The heat was collected in the solar flat plate collector through the working fluid.

The gained heat was supplied to the drying chamber.so, thedrying chamber gets the additional heat because the chamber also 
www.rspsciencehub.com

receives the solar radiations through the glass cover.

$>$ The waffles are arranged and separated one by one in the drying chamber.

$>$ The solar radiations and gained heat which is collected from the collector falls on the waffles and absorbed by waffles. Finally the waffles are dryed.

\section{Result and discussion}

\section{Performance Testing of Mixed Mode Solar Dryer:}

We now consider the performance analysis of solar dryer.

The experiment was performed on March $21^{\mathrm{St}}$ and $23^{\text {rd }}, 2019$ from 9:00AM to 5:00PM for every one hour temperature.

\section{First Day Measurement:}

In the month of March $21^{\text {st }} 2019$, the maximum outlet temperature of flat-plate solar air heater is $75.1^{\circ} \mathrm{C}$ at $1: 00 \mathrm{PM}$ and in drying chamber $81^{\circ} \mathrm{C}$ is obtained due to presence of glass at the top of the drying chamber.

Table 2.Performance of Solar Dryer in First Day Performance calculation:

\begin{tabular}{|c|c|c|c|c|c|c|c|}
\hline \multirow{2}{*}{$\begin{array}{r}\text { Time } \\
\text { (h) }\end{array}$} & \multicolumn{4}{|c|}{ Temperature $\left({ }^{(} \mathrm{C}\right)$} & \multirow{2}{*}{$\begin{array}{c}\text { Heat Gain } \\
Q_{u} \\
(W)\end{array}$} & \multirow{2}{*}{$\begin{array}{c}\text { Heat Loss } \\
Q_{1} \\
\text { (W) }\end{array}$} & \multirow{2}{*}{$\begin{array}{l}\text { Efficiency } \\
\qquad(\%)\end{array}$} \\
\hline & $\begin{array}{c}\text { Surface } \\
\text { of } \\
\text { Glass }\end{array}$ & $\begin{array}{c}\text { Absorber } \\
\text { Plate }\end{array}$ & $\begin{array}{r}\text { Collector } \\
\text { outlet }\end{array}$ & $\begin{array}{c}\text { Drying } \\
\text { chamber }\end{array}$ & & & \\
\hline 9.00 & 43 & 00 & & 0 & 156.80 & 188.23 & 33 \\
\hline 10:00 & 48 & 105.6 & 3 & 62 & 227.61 & 252.32 & 35.13 \\
\hline 11:00 & 55 & 15 & 65.7 & 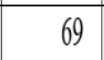 & 292.52 & 314.14 & 36.4 \\
\hline $12: 00$ & 58 & 35 & 72.8 & 77 & 343.94 & 306.87 & 40.1 \\
\hline $1: 00$ & 62 & 131.27 & 75.1 & 81 & 354.06 & 311.47 & 40.7 \\
\hline $2: 00$ & 62 & 127.25 & 73.5 & 79 & 344.78 & 296.22 & 41.59 \\
\hline 3:00 & 54 & 113.6 & 68.6 & 77 & 308.54 & 207.37 & 44.35 \\
\hline 4:00 & 48 & 101.25 & 59.3 & 64 & 238.57 & 148.97 & 48.12 \\
\hline 5:00 & 38 & 85.57 & 46.9 & 48 & 142.47 & 16.96 & 51.06 \\
\hline
\end{tabular}

Heat gain $(\mathrm{Qu})=\mathrm{m} \times \mathrm{Cp} \times(\mathrm{Tfo}-\mathrm{Tfi})$

$$
=8.388 \times 10^{-3} \times 1005 \times(48.6-30)
$$

$(\mathrm{Qu})=156.80 \mathrm{~W}$

Average heat gain $=267.70 \mathrm{~W}$

Heat loss $(\mathrm{Q} 1)=(\mathrm{S} \times \mathrm{Ap})-\mathrm{Qu}$
Volume 03 Issue 01S January 2021

$$
\mathrm{Q} 1=(605 \times 1.46 \times 0.56)-267.70
$$

$=226.95 \mathrm{~W}$

$$
\begin{gathered}
\text { Efficiency }=(\mathrm{Qu} /(\mathrm{IT} \times \mathrm{Ac})) \times 100 \\
\begin{array}{c}
\eta=(267.70 /(720 \times 1.5 \times 0.6)) \times 100 \\
\eta=41.31 \%
\end{array}
\end{gathered}
$$

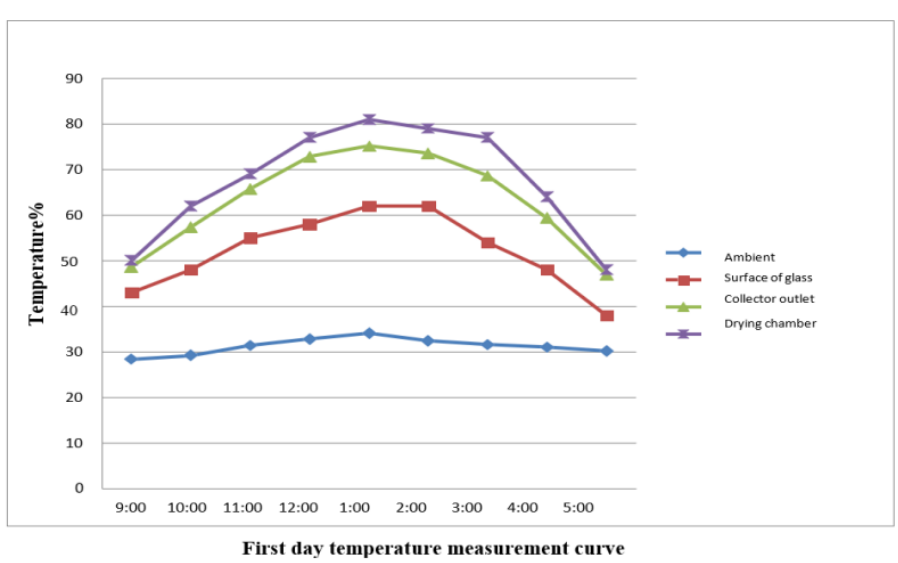

Fig.1. First Day Measurement curve

In the month of March 21 ${ }^{\text {st }}$, 2019At 9:00AM the outlet temperature of air was $48.6^{\circ} \mathrm{C}$ and in drying chamber $50^{\circ} \mathrm{C}$ At 1:00PM the outlet temperature of air was $75.1^{\circ} \mathrm{C}$ and in drying chamber $81^{\circ} \mathrm{C}$ At 5:00PM the outlet temperature of air was $46.9^{\circ} \mathrm{C}$ and in drying chamber $48^{\circ} \mathrm{C}$.

\section{Second Day Measurement:}

The maximum outlet temperature of flat-plate solar air heater is $68.7^{\circ} \mathrm{C}$ at $1: 00 \mathrm{PM}$ and in drying chamber $71^{\circ} \mathrm{C}$ is obtained due to presence of glass at the top of the drying chamber.

\section{Performance calculation:}

Heat gain $(\mathrm{Qu})=\mathrm{m} \times \mathrm{Cp} \times\left(\mathrm{Tfo}^{-} \mathrm{Tfi}\right)$

$(\mathrm{Qu})=101.16 \mathrm{~W}$

$$
=8.388 \times 10^{-3} \times 1005 \times(41-29)
$$

Average heat gain $=231.17 \mathrm{~W}$

Heat loss $(\mathrm{Ql})=(\mathrm{S} \times \mathrm{Ap})-\mathrm{Qu}$

$\mathrm{Q} 1=(605 \times 1.46 \times 0.56)-231.17=263.48 \mathrm{~W}$

\section{Performance of solar dryer in second day}

Efficiency $=\left(Q_{u} /\left(\mathrm{IT} \times \mathrm{Ac}_{\mathrm{c}}\right)\right) \times 100$

$\eta=(231.17 /(720 \times 1.5 \times 0.6)) \times 100$

$\eta=35.67 \%$

In the month of March 23 ${ }^{\text {rd }}, 2019$ At 9:00AM the outlet temperature of air was $41^{\circ} \mathrm{C}$ and in drying chamber $43^{\circ} \mathrm{C}$ At 1:00PM the outlet temperature 


\section{www.rspsciencehub.com}

of air was $68.7^{\circ} \mathrm{C}$ and in drying chamber $71^{\circ} \mathrm{C} \mathrm{At}$ 5:00PM the outlet temperature of air wa $45.2^{\circ} \mathrm{C}$ and in drying chamber $46^{\circ} \mathrm{C}$.

Table.3. Performance of solar dryer in second day

\begin{tabular}{|c|c|c|c|c|c|c|c|}
\hline \multirow{2}{*}{$\begin{array}{r}\text { Time } \\
(\mathrm{h})\end{array}$} & \multicolumn{4}{|c|}{ Temperature $\left({ }^{\circ} \mathrm{C}\right)$} & \multirow{2}{*}{$\begin{array}{c}\text { Heat } \\
\text { Gain } Q_{u} \\
(W)\end{array}$} & \multirow{2}{*}{$\begin{array}{c}\text { Heat } \\
\text { Loss } Q_{1} \\
(\mathrm{~W})\end{array}$} & \multirow{2}{*}{$\begin{array}{c}\text { Efficiency } \\
(\%)\end{array}$} \\
\hline & $\begin{array}{c}\text { Surface } \\
\text { of } \\
\text { Glass }\end{array}$ & $\begin{array}{c}\text { Absorber } \\
\text { Plate }\end{array}$ & $\begin{array}{c}\text { Collector } \\
\text { outlet }\end{array}$ & $\begin{array}{l}\text { Drying } \\
\text { chamber }\end{array}$ & & & \\
\hline 9:00 & 38 & 21 & 41 & 43 & 101.16 & 243.87 & 21.29 \\
\hline $10: 00$ & 46 & 92.25 & 51.8 & 52 & 183.77 & 296.16 & 28.36 \\
\hline 11:00 & 54 & 109.26 & 61.6 & 64 & 257.96 & 348.7 & 32.1 \\
\hline $12: 00$ & 60 & 116.58 & 67.7 & 69 & 300.95 & 349.86 & 35.1 \\
\hline $1: 00$ & 58 & 118.35 & 68.7 & 71 & 309.38 & 356.15 & 35.6 \\
\hline $2: 00$ & 54 & 109.36 & 67 & 70 & 303.48 & 337.52 & 36.61 \\
\hline $3: 00$ & 50 & 103.87 & 63.3 & 65 & 280.72 & 235.19 & 40.35 \\
\hline 4:00 & 46 & 97.65 & 55.5 & 60 & 214.96 & 172.58 & 43.35 \\
\hline 5:00 & 38 & 84.35 & 45.2 & 46 & 128.14 & 31.29 & 45.93 \\
\hline
\end{tabular}

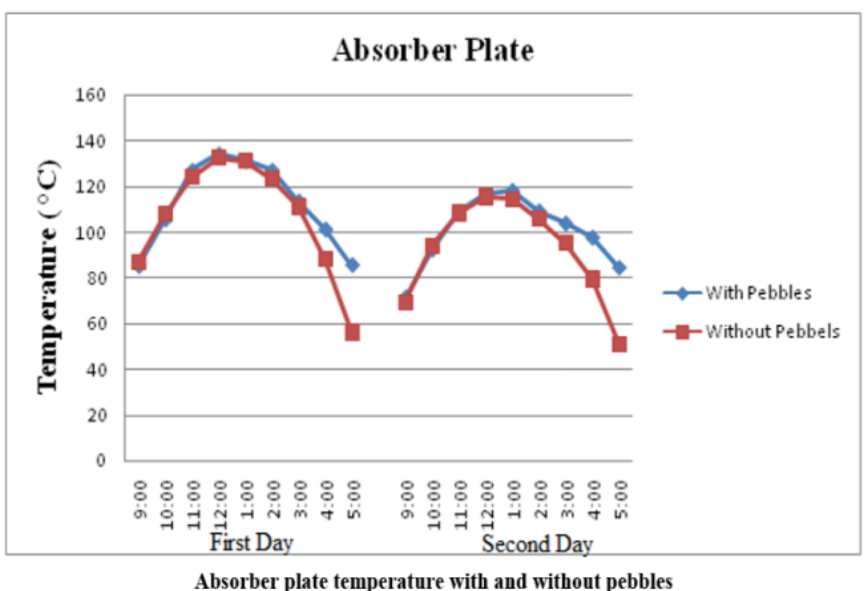

Fig.2.Second Day Measurement curve

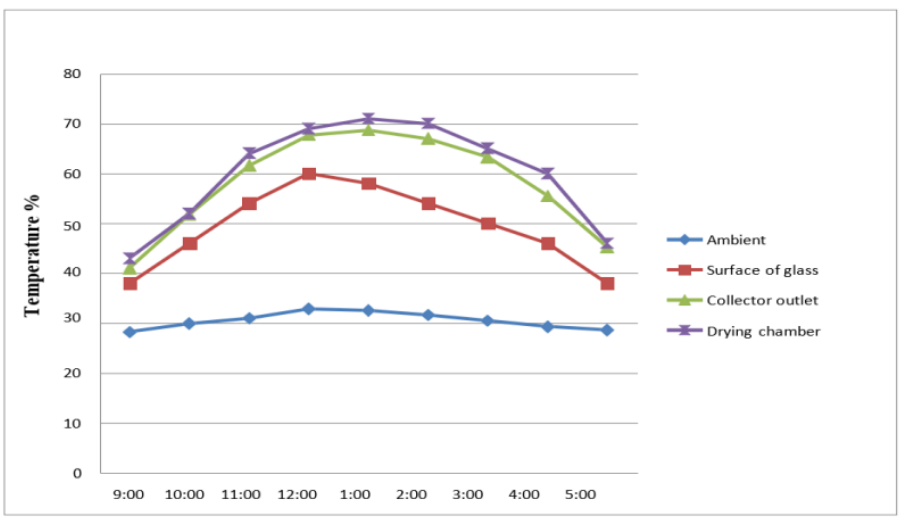

Second Day temperature measurement curve

\section{Fig.3.Comparison of Absorber Plate Surface temperature}

Volume 03 Issue $01 S$ January 2021

Due to presence of pebbles the surface temperature of an absorber plate is much higher than surface temperature without pebbles, because pebbles are sensible heat storing material. So that the efficiency of a solar air heater is much higher in evening session.

\section{Conclusion}

From the above design and construction, it has been concluded that solar radiation can be effectively and efficiently utilized by the mixed mode solar dryer for drying the waffles. From the result which has been obtained, the area of the collector (i.e. $0.90 \mathrm{~m}^{2}$ ) is small as portable. The flat-plate solar air heater with storage bed (i.e. pebbles) can be characterized by means of its daily efficiency, determining its daily average characteristics parameter. The average temperature output of solar air heater is $59^{\circ} \mathrm{C}$ and the efficiency of a dryer is $37 \%$. This temperature is suitable of drying agricultural product also. The time to dry the product is less when compare with open sun drying. Due to presence of pebbles the temperature outlet is much higher when compare to without pebbles during evening session. This project helps us not only increase the temperature efficiency, but also bringing up a new phase in alternative trend in the usage of food processing. It help us to gain lot of technical knowledge which will help in future.

\section{References}

[1] LyesBennamoun, AzeddineBelhamri ; Design and simulation of a solar dryer for agriculture products; Journal of Food Engineering 59 (2003)259-266.

[2] Radivoj M. Topić1, NenadLj. Ćuprić2, Milan R. Božović3; "Muechas"- design and construction of an active solar dryer for biological materials; International Journal of Mechanical Engineering and Applications 2013; 1(2):49-58.

[3] SermJanjai; A greenhouse type solar dryer for small-scale dried food Industries; International journal of energy and environment; Volume 3, Issue 3, 2012pp.383-398.

[4] Shobhana Singh and Subodh Kumar; Comparative Thermal Performance Study of Indirect and Mixed-mode Solar Dryers; International Journal of Sustainable Energy Development (IJSED), Volume 1, Issues 
$1 / 2 / 3 / 4$,

March/June/September/December2012.

[5] Chandrakumar B Pardhi1 and Jiwanlal L Bhagoria; Development and performance evaluation of mixed-mode solar dryer with forced convection; Pardhi and Bhagoria; International Journal of Energy and Environmental Engineering 2013,4:23.

[6] A.K. Kamble1, I.L.Pardeshi2, P.L. Singh3 and G.S. Ade4; Drying of chilli using solar cabinet dryer coupled with gravel bed heat storage system.

[7] Y M Yunus, H H Al-Kayiem; Simulation of Hybrid Solar Dryer; International Conferenceon Energy and Environment 2013(ICEE2013).

[8] A I Oliva, R D Maldonado, E A Díaz, A I Montalvo ; A high absorbance material for solar collectors applications; Congresson Materials Science and Engineering (CNCIMMexico2012) IOPPublishing.

[9] Sukhatme S.P., Solar-Energy-Principles of Thermal Collection and Storage; Tata McGraw Hill Publishing Company Limited,1996.

[10]C.P. Kothandaraman, S.Subramanyan; Heat and Mass Transfer Data Book; New Age International (P) Ltd.1989. 